\title{
Case of Insulinoma in a 2-Months-Old Infant
}

Niluh Putu Wida Pangestika ${ }^{1 *}$, I Made Arimbawa ${ }^{1}$, I Made Darma Yuda ${ }^{1}$, Ida Bagus Gede Suparyatha ${ }^{1}$, Dyah Kanya Wati ${ }^{1}$, I Nyoman Budi Hartawan ${ }^{1}$, Kadek Deddy Ariyanta ${ }^{2}$, I Made Darmajaya ${ }^{2}$, I Putu Kurniyanta ${ }^{3}$, Luh Putu lin Indrayani Maker ${ }^{4}$, Pande Putu Yuli Anandasari ${ }^{5}$, I Nyoman Wande ${ }^{6}$

${ }^{1}$ Department of Child Health, Medical School, Udayana University, Sanglah Hospital, Denpasar, Bali, Indonesia; ${ }^{2}$ Department of Child Surgical, Medical School, Udayana University, Sanglah Hospital, Denpasar, Bali, Indonesia; ${ }^{3}$ Department of Anesthesiology and Intensive Care, Medical School, Udayana University, Sanglah Hospital, Denpasar, Bali, Indonesia; ${ }^{4}$ Department of PathologyAnatomy, Medical School, Udayana University, Sanglah Hospital, Denpasar, Bali, Indonesia; ${ }^{5}$ Department of Radiology, Medical School, Udayana University, Sanglah Hospital, Denpasar, Bali, Indonesia; ${ }^{6}$ Department of Pathology-Clinic, Medical School, Udayana University, Sanglah Hospital, Denpasar, Bali, Indonesia

Edited by: Ksenija Bogoeva-Kostovska Citation: Pangestika NPW, Arimbawa IM, Yuda IMD Suparyatha IBG, Wati DK, Hartawan INB, Ariyanta KD,
. Darmajaya IM, Kurniyanta IP, Maker LPII, Anandasari PPY Open-Access Maced J Med Sci. 2022 Feb 23; 10(C):89-94

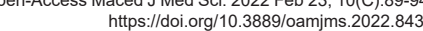
Keywords: Congenital hyperinsulinism; Hypoglycemia;

Insulinoma Correspondence: Niluh Putu Wida Pangestika, Department of Child Health, Faculty of Medicine, Udayana University/Sanglah Hospital, Diponegoro Street, Denpasar, Bali, Indonesia. E-mail: tikawida91@gmail.com Received: 29-Dec-2021 Accepted: 13-Feb-2022

Copyright: ๑ 2022 Niluh Putu Wida Pangestika, I Made Arimbawa, I Made Darma Yuda, Ida Bagus Gede Suparyatha, Dyah Kanya Wati,

Nyoman Budi Hartawan, Kadek Deddy Ariyanta, I Made Darmajaya, I Putu Kurniyanta, Luh Putu lin Indrayani Maker, Pande Putu Yuli Anandasari,

INyoman Wande
Funding: This research did not receive any financial

Competing Interest: The authors have declared that no competing interest exists Open Access: This is an open-access article distributed
under the terms of the Creative Commons AtributionNonCommercial 4.0 International License (CC BY-NC 4.0)

\begin{abstract}
INTRODUCTION: Insulinoma is congenital hyperinsulinism of infancy $(\mathrm{CHI})$. It is a type of functional neuroendocrine tumor (NET) in the pancreas that manifests with persistent hypoglycemia caused by inappropriately high secretion of insulin (hyperinsulinemia). Comprehensive and multidisciplinary management is required for a better outcome.

CASE PRESENTATION: A 2-months-old girl came to the Emergency unit Sanglah Hospital, with a chief complain of seizure. The patient had a low blood glucose level, high fasting insulin, high LDH, computed tomography of the abdomen result showed isodense heterogeneous lesions border in the cauda pancreas with size $1.32 \times 1.24$ $\times 1.35 \mathrm{~cm}$. The anatomy-pathological result showed pancreatic neuroendocrine tumor WHO Grade II, functional, consistent, and clinically to insulinoma on the tail of the pancreas. The patient was treated with hydrocortisone, nifedipine, and octreotide. The patient underwent laparotomy partial pancreatectomy. In post-surgery condition, she had good drink tolerance, no episode of recurrent seizure, and blood glucose was controlled.
\end{abstract}

CONCLUSION: Insulinoma is a rare disease. The diagnosis was challenging. This case report presents the diagnostic work-up and management of a patient with a persistent hypoglycemia condition that was diagnosed as insulinoma.

\section{Introduction}

Hypoglycemia is a common clinical problem in neonates, less common in infants and toddlers, and is rare in older children. Hypoglycemia is a condition caused by a low blood glucose level, and a variety of symptoms can occur. Hypoglycemia is commonly classified into transient or persistent types. Persistent hypoglycemia is defined as hypoglycemia lasting for over $48 \mathrm{~h}$ or appearing first after $48 \mathrm{~h}$ of life or inpatient who requires a high glucose infusion rate (usually over $10-12 \mathrm{mg} / \mathrm{kg} / \mathrm{min}$ ) to maintain normal glucose level [1].

Insulinoma is functioning well-differentiated pancreatic neuroendocrine neoplasm composed of insulin-producing and proinsulin-producing cells, with uncontrolled insulin secretion causing a hypoglycemic syndrome. Insulinomas have an estimated annual incidence of 0.4 cases per 100.000 population [2], [3].
The etiology of insulinoma is not clearly understood. In patient with insulinoma, insulin still gets secreted, even when plasma glucose concentration is low [4]

The classical diagnosis of insulinoma is the Whipple triad (presence of hypoglycemic symptoms, low blood glucose level at the time of symptom onset, improvement of symptoms after glucose intake) [2]. Diagnosis of insulinoma is often delayed because signs and symptoms that occur following hypersecretion of insulin by this tumor and consequent hypoglycemia and neuroglycopenia are commonly seen in a variety of other diseases. Prompt and early diagnosis of insulinoma is very important because it can cause recurrent hypoglycemia which can consequently cause irreversible neurologic damage [4], [5]. Management of insulinoma aims to maintain normal blood glucose levels. Most insulinomas are benign, solitary lesions that are complete surgical excision for cure [6]. 


\section{Case Report}

A 2-months-old girl was referred from Prof. Dr. WZ Johannes, Kupang district hospital with persistent hypoglycemia. The patient was being hospitalized because of low blood sugar since birth. The patient was born from healthy and non-consanguineous parents with 39-40 weeks of gestational age by C-section, due to macrosomia. Weight and height of birth were $4800 \mathrm{~g}$ and $53 \mathrm{~cm}$, respectively. She was born vigorously and there was no history of respiratory distress. The blood sugar level was $20 \mathrm{mg} / \mathrm{dL}$. The patient was treated at NICU for 3 weeks. The patient got glucose infusion (GIR was unknown), and intravenous dexamethasone $0.5 \mathrm{mg}$ every $8 \mathrm{~h}(0.1 \mathrm{mg} / \mathrm{kg} /$ times $)$. After being treated for 3 weeks, the patient was sent home. One day after being treated at home, the patient got a generalized tonic-clonic seizure. The blood sugar level was $8 \mathrm{mg} / \mathrm{dL}$. The patient was treated at Prof. Dr. WZ Johannes district hospital again for 1 week. The patient got glucose infusion (GIR was unknown), intravenous dexamethasone, and anticonvulsant. The blood glucose level increased, and the patient was treated at home with oral dexamethasone and oral phenobarbital. 3 weeks after that, the patient got a seizure again. The patient was brought to Prof. Dr. WZ Johannes, Kupang district hospital. Physical examination revealed lethargic, no bulging fontanelle, otherwise in the normal range. The blood sugar level was $9 \mathrm{mg} / \mathrm{dL}$. Therefore, the patient was diagnosed seizure caused by hypoglycemia. The patient was treated with glucose infusion (GIR was unknown), intravenous dexamethasone $3 \mathrm{mg}$ every $8 \mathrm{~h}$ $(0.6 \mathrm{mg} / \mathrm{kg} /$ times$)$, intravenous phenobarbital $7.5 \mathrm{mg}$ every $12 \mathrm{~h}$ (4 mg/kg/day), and referred to Sanglah Hospital.

On the $1^{\text {st }}$ day of admission, the patient seemed lethargic. The patient was said to be less active than before, refused to drink. After $5 \mathrm{~h}$ of observation in the emergency unit, the patient presented a generalized tonic-clonic seizure for less than $5 \mathrm{~min}$. Physical examination revealed lethargic, no bulging fontanelle, no meningeal sign, normal neurological reflexes, no neurological deficit, otherwise in the normal range. The CBC examination was within normal limit, electrolyte within normal limit, blood sugar level was $23 \mathrm{mg} / \mathrm{dL}$. The patient was consulted to Nutrition and Metabolic disease division to evaluate suspicion of hypoglycemia due to metabolic disease. However, the urinalysis examination revealed no ketonuria, no glucosuria, no sediment erythrocyte, no sediment leukocyte, no proteinuria, and nitrite was negative. Blood Gas Analysis showed blood $\mathrm{pH} 7.46, \mathrm{HCO} 3-$ was $28.30 \mathrm{mmol} / \mathrm{L}$, Base excess was $4.4 \mathrm{mmol} / \mathrm{L}, \mathrm{pCO} 2$ was $41.1 \mathrm{mmHg}$, and pO2 was $123.2 \mathrm{mmHg}$. The patient can not undergo a MRI to detect if brain insult was developed because these modalities can not be done in Sanglah Hospital. She was given D10\% $2 \mathrm{ml} / \mathrm{kg}$ (GIR 4) boluses when the blood glucose level was below $25 \mathrm{mg} / \mathrm{dL}$, Standart formula $60 \mathrm{ml}$ every $2 \mathrm{~h}$, suppository diazepam and then transferred to a regular ward.
On the $2^{\text {nd }}$ day of admission, the blood glucose level was still unstable. Range of blood glucose level found within $10 \mathrm{mg} / \mathrm{dL}$ until $102 \mathrm{mg} / \mathrm{dL}$. The patient got seizures twice with blood glucose level was low (undetected) and $10 \mathrm{mg} / \mathrm{dL}$, respectively. The patient was consulted to the endocrinology division for persistent hypoglycemia. In addition to previous treatment, the patient was given glucose infusion (GIR was increased gradually to 12), hydrocortisone $2 \mathrm{mg} / \mathrm{kg} / \mathrm{dose}$ every $8 \mathrm{~h}$, but the episode of hypoglycemia persisted. On the $8^{\text {th }}$ day, the patient's blood glucose was $20 \mathrm{mg} / \mathrm{dL}$, there was no seizure, no lethargy. The patient was given additional nifedipine with initial dose $0.3 \mathrm{mg} / \mathrm{kg} /$ day. On $9^{\text {th }}$ day, intravenous hydrocortisone was stopped because of patient's intravenous access was difficult. Octreotide started in dose of 10 microgram $/ \mathrm{kg} / \mathrm{dose}$ subcutaneously.

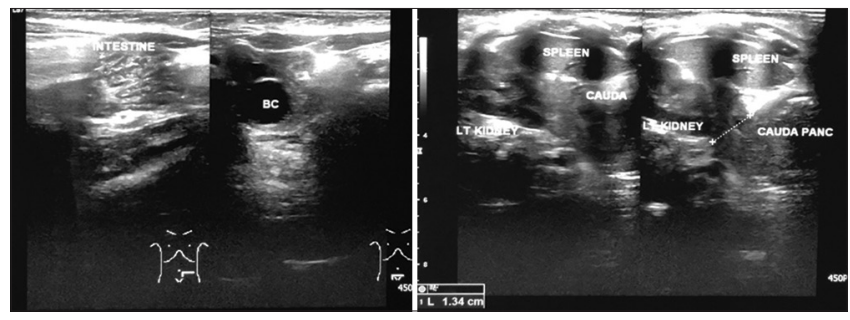

Figure 1: The computed tomography of abdomen result showed prominent intestine at left abdomen. No abnormality of liver, gallbladder, spleen, and the kidney

Patient had high fasting insulin level (92.1 $\mu \mathrm{lU} / \mathrm{ml}$, reference range 3.2-28.5 $\mu \mathrm{lU} / \mathrm{ml}$ ), normal growth hormone level was $13.5 \mathrm{ng} / \mathrm{mL}$, TSHs level was $1.99 \mu \mathrm{IU} / \mathrm{mL}$ (reference range $0.27-4.2 \mu \mathrm{IU} / \mathrm{mL}$ ), Free T4 level was $1.35 \mathrm{ng} / \mathrm{dL}$ (reference range $0.93-1.7 \mathrm{ng} / \mathrm{dL}$ ), LDH was 949 (reference range 240-480 U/L), CEA level was 2.51 (reference range $<3.8 \mathrm{ng} / \mathrm{mL}$ ), CA 19-9 was 19.75 (reference range $<27 \mathrm{U} / \mathrm{mL}$ ). The patient was subsequently diagnosed with persistent hypoglycemia due to hyperinsulinemia. Further examination by abdominal ultrasonography revealed prominent intestine at the left abdomen, no abnormality of, the liver, gallbladder, spleen, and kidney (Figure 1). Computed tomography (CT) scan of the abdomen with contrast showed isodense heterogeneous lesions border in the cauda pancreas with size $1.32 \times 1.24 \times 1.35 \mathrm{~cm}$. In contrast, showed homogeneous contrast enhancement (Figure 2).

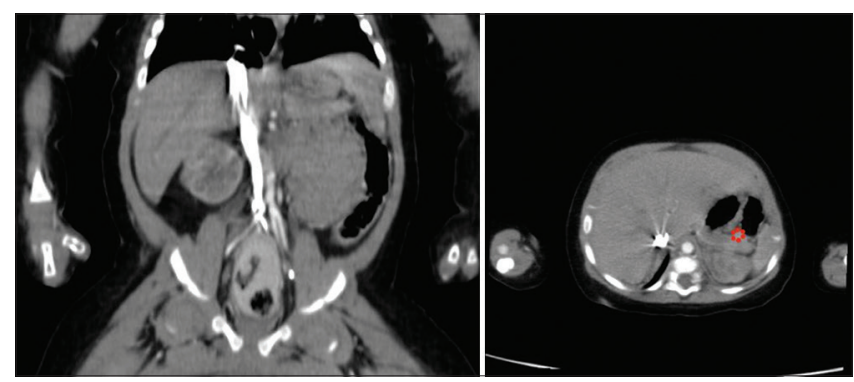

Figure 2: The computed tomography of abdomen result showed isodense heterogeneous lesions border in the cauda pancreas with size $1.32 \times 1.24 \times 1.35 \mathrm{~cm}$. In contrast showed homogeneous contrast enhancement 
The blood glucose was still below the expected level, although all treatments had been given to the patient. Due to poor response of therapy, the patient then consulted to pediatric surgery for consideration surgery option and subsequently was decided partial pancreatectomy (Figure 3). The pancreatomy was done by the laparotomy method. From the anatomypathological examination, result showed histomorphology reference as pancreatic NET (PanNET) WHO grade II, functional, consistence, and clinically to insulinoma on the tail of the pancreas (Figure 4). Ki-67 expression was done by immunohistochemistry showed $5 \%$ of the cell lesion.

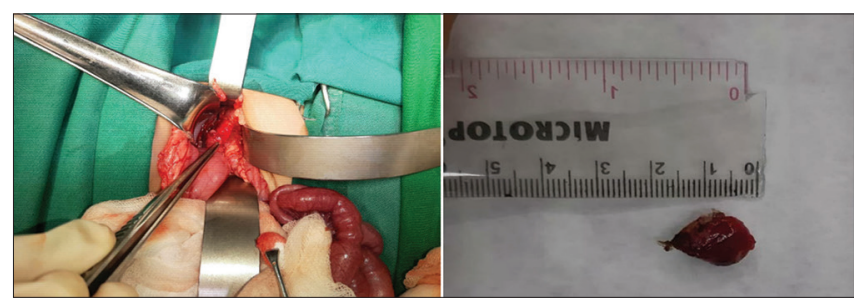

Figure 3: Laparotomy partial pancreatectomy was performed

The patient was admitted to pediatric intensive care unit after laparatomy partial pancreatectomy. The general condition was good, there was no lethargic, no seizure had good tolerance to drink, and no sign of infection. Patient developed hyperglycemia after the surgery. The heel-prick glucose level ranges between 223 and $307 \mathrm{mg} / \mathrm{dL}$. The patient was given intravenous antibiotic, analgesic, and insulin 1 unit every $6 \mathrm{~h}$ when glucose level $>200 \mathrm{mg} / \mathrm{dL}$. Patient was checked insulin and c-peptide after surgery. Patient fasting insulin level was <2 $\mu \mathrm{IU} / \mathrm{ml}$, (reference range 3.2-28.5 $\mu \mathrm{lU} / \mathrm{ml}$ ), low C-Peptide level $(0.4 \mathrm{ng} / \mathrm{mL}$, reference range $0.9-7.1 \mathrm{ng} / \mathrm{mL})$. On the $4^{\text {th }}$ day after surgery, the patient was transferred to intermediate ward. The blood glucose was normal. The heel-prick glucose level ranges between 70 and $120 \mathrm{mg} /$ $\mathrm{dL}$. On the $8^{\text {th }}$ day, the patient was transferred to a regular ward. The general condition was good, there was no lethargic, no seizure had good tolerance to drink, and no sign of infection. On the $13^{\text {th }}$ day after surgery, the patient was discharged and being followed up regularly every month in the pediatric endocrinology clinic.

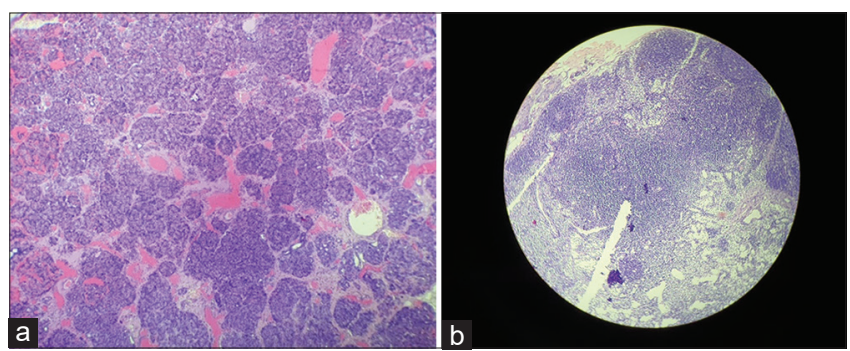

Figure 4: (a) Pancreatic tissue comprises the proliferation of neoplastic cells, forming an insular structure, partially tubuloacinar and trabecular, solid, infiltrative between the connective tissue stroma. These cells with oval, spherical morphology, partially cytoplasmic eosinophilic granular cytoplasm, broad oval spherical nuclei mild N/C ratio increased, mild nuclei pleomorphia, chromatin salt and pepper partly hyperchromatic with partially visible nuclei, irregular nuclei. Mitosis 1/10 LPB. Intravenous invasion and negative perineural invasion. (b) Connective tissue, blood vessels, fat and 1 lymph node structure

\section{Discussion}

Hypoglycemia occurs when the blood glucose level is below the requirement for metabolism. The AAP guidelines recommend low blood glucose levels when patient with plasma glucose $<45 \mathrm{mg} / \mathrm{dL}$. An infant with hypoglycemia shows no pathognomonic signs, and these signs can be seen in other disorders. The signs include lethargy, irritability, tremors, jitteriness, flopping, apnea, poor feeding, cyanosis, tachypnea, weak or high-pitched cry. Seizure and coma usually occur with severe, prolonged, and repetitive hypoglycemia. Symptoms of hypoglycemia in children can occur through neuroglycopenic or autonomic pathways. Autonomic symptoms, through activation of sympathetic pathways, include tachycardia, anxiety, tremors, sweating, vomiting, and hypothermia. Neuroglycopenic symptoms such as headaches, lethargy, or visual disturbance, are results from declined glucose level into the central nervous system. Seizure and coma usually occur with severe, prolonged, and repetitive hypoglycemia [1], [2]. The patient came to the emergency department due to lethargy, less active than before, refused to drink, and seizure. The blood glucose level was $23 \mathrm{mg} / \mathrm{dL}$, and the patient was given D10\% $2 \mathrm{ml} / \mathrm{kg}$ boluses when the blood glucose level was below $25 \mathrm{mg} / \mathrm{dL}$.

Hypoglycemia is commonly classified into transient or persistent type. Transient hypoglycemia had been associated with hypoglycemia in infant such as premature or postmature, intrauterine growth retardation, large gestational age or small gestational age, hypothermia or hyperthermia, hypoxia or asphyxia, illness (respiratory distress, and sepsis), polycythemia, shock, perinatal stress, infant of gestational or insulindependent (IDM) diabetic mother, maternal intrapartum glucose administration, maternal on hypoglycemic agents, umbilical artery catheter near vessels supplying the pancreas that stimulate insulin release, insufficient calory intake or delayed onset of feeding. Persistent hypoglycemia is defined as hypoglycemia lasting for more than $48 \mathrm{~h}$ or appears first after $48 \mathrm{~h}$ of life or in patient who require a high glucose infusion rate (usually over than 10-12 $\mathrm{mg} / \mathrm{kg} / \mathrm{min}$ ) to maintain normal glucose level [1]. Persistent hypoglycemia can be caused by congenital hyperinsulinism $(\mathrm{CHI})$, endocrine disorders (growth hormone deficiency, adrenal insufficiency, congenital hypopituitarism, congenital adrenocorticotropic hormone deficiency or familial glucocorticoid deficiency, beckwithwiedmann syndrome, turner mosaic syndrome, and kabuki syndrome), inborn error of metabolism (glycogen storage disorder, gluconeogenesis disorder, and fatty acid oxidation disorder) [1], [2]. The patient was born by cesarean section due to macrosomia, vigorously, with a history of large gestational age, no history of hypothermia, no history of infection. Patient with persistent hypoglycemia caused by $\mathrm{CHI}$ that required high glucose infusion rate to maintain blood glucose level. 
Insulinoma is a $\mathrm{CHI}$. It is a type of functional NET in the pancreas that manifests with persistent hypoglycemia caused by inappropriately high secretion of insulin (hyperinsulinemia). In most cases, a single tumor develops in the beta cells (the insulin-producing cells) within the pancreas. In a very small number of cases $(1-3 \%)$ the tumor will develop in insulinproducing cells [3]. Multiple endocrine neoplasia type 1 (MEN1) is a disorder characterized by a predisposition to the pituitary, parathyroid, and entero-pancreatic tumors. When insulinomas are associated with MEN1, a mutation in the MEN1 gene at chromosome 11q13 is typically present in most cases. This phenomenon has suggested a role of MEN1 as a tumor suppressor gene, requiring the inactivation of both alleles for clonal expansion and tumor development [3]. The MEN1 gene consists of ten exons spanning $9 \mathrm{~kb}$ of genomic DNA and encodes a 610- amino acid protein product termed menin. Menin is ubiquitously expressed in both endocrine and nonendocrine tissues. Predominantly described as a transcriptional regulator, menin interacts with a wide variety of nuclear and cytosolic proteins, which suggests that menin may be involved in multiple biological pathways leading to tumor formation [4].

Diagnosis of insulinoma is often delayed because signs and symptoms are commonly seen in a variety of other diseases [5]. Noninvasive localization studies 18F-Dopa PET-CT scan can be used to diagnose $\mathrm{CHI}$. It can differentiate focal or diffuse $\mathrm{CHI}$. Other modalities that can be used to diagnose insulinoma include transabdominal ultrasonography, CT, and MRI. While these modalities have the advantages of being readily available and noninvasive, the results are often disappointing, especially in insulinomas $<2 \mathrm{~cm}$ in size. The sensitivities of transabdominal ultrasonography, CT, and MRI are 9-67\%, 16-73\%, and $7-45 \%$, respectively [4]. Routine histopathology results in macroscopy, insulinoma usually presents as solitary, round, well-demarcated tumor, with grayish-white to yellowish-tan or occasionally hemorrhagic cut surfaces. About $80 \%$ of insulinomas are much smaller $(1-2 \mathrm{~cm}$ in diameter) than other functioning PanNETs, making their diagnosis by morphological and/or functional imaging sometimes difficult. An estimated $1.6 \%$ of insulinomas are $<1 \mathrm{~cm}$ in diameter. Insulinomas that metastasize are typical $>2 \mathrm{~cm}$, with a mean diameter of $3 \mathrm{~cm}$. In microscopy, the insulinomas growth pattern is either trabecular or solid. There is sometimes a tabuloacinar growth pattern with psammoma bodies, as seen in somatostatin-producing PanNETs. Occasionally there are entrapped non-neoplastic ducts and intense sclerosis. Stromal deposits of islet amyloid polypeptide (also called amylin) are specific to insulinomas but occur in only $5 \%$ of cases. The tumors cells are in close contact with a fine network of endothelial cells [2]. Diagnostic algorithm of insulinoma is shown in Figure 5.

The patient had a low blood glucose level, and high fasting insulin. The patient can not undergo an
18F-Dopa PET-CT scan because these modalities can not be done in Denpasar, Bali. The patient underwent abdomen ultrasonography, the result is a prominent intestine at the left abdomen, however, the pancreas still could not be evaluated well. The CT scan of the abdomen revealed isodense heterogeneous lesions border in the cauda pancreas with size $1.32 \times 1.24 \times$ $1.35 \mathrm{~cm}$. In contrast, showing homogeneous contrast enhancement. The diagnosis of insulinoma was confirmed by anatomy-pathological results that showed PanNET WHO Grade II, functional, consistent, and clinically to insulinoma on the tail of the pancreas. Ki-67 expression was done by immunohistochemistry showed $5 \%$ of the cell lesion.

Dietary modification and pharmacologic agents play a crucial role in the management of insulinomas in patients who are not candidates for surgical resection or those who are awaiting surgery. The dietary modification includes consumption of frequent throughout the day and middle of the night to avoid symptomatic hypoglycemia. Nearly all of the patients require a high rate of glucose infusion rate. The initial drug of choice is diazoxide, a benzothiadiazide. Diazoxide inhibits insulin release from $\beta$ cells by stimulating $\alpha$-adrenergic receptors. Diazoxide also inhibits cyclic adenosine monophosphate phosphodiesterase, which enhances glycogenolysis and has a hyperglycemic effect. Diazoxide doses range from 5 to $20 \mathrm{mg} / \mathrm{kg} /$ day divided into three doses. Somatostatin analog (Octreotide) is used in patients with diazoxide unresponsiveness. Octreotide inhibits insulin secretion, through decreased calcium transfer and insulin-promoter gene activity, as well as affecting the K-ATP channel. The somatostatin analog octreotide binds with high affinity to the second of the five subtypes of the somatostatin receptor. This receptor is present in varying degrees on insulinomas, accounting for the variability of response. However, this class of agents can decrease plasma insulin levels and alleviate symptoms in $40 \%$ to $60 \%$ of patients. Calcium-channel blockers like nifedipine have also been reported to be of some use to inhibit insulin secretion [6]. Most insulinomas are benign, solitary lesions that are complete surgical excision for a cure. Insulinomas tend to be compact and encapsulated, presenting a clear dissection plane between the tumor and the surrounding pancreas. It is important to remove the tumor with the capsule completely to prevent a local recurrence. Segmental resection of the pancreas, distal pancreatectomy, or rarely a pancreaticoduodenectomy, may be required for lesions near the pancreatic duct or involving a large portion of the pancreatic substance. Hard tumors, infiltrating, creating puckering of surrounding tissue, or causing pancreatic duct dilation should raise a suspicion of malignancy, and therefore also be removed by formal resection [6]. The patient was given hydrocortisone $2 \mathrm{mg} / \mathrm{kg} / \mathrm{day}$, nifedipine 


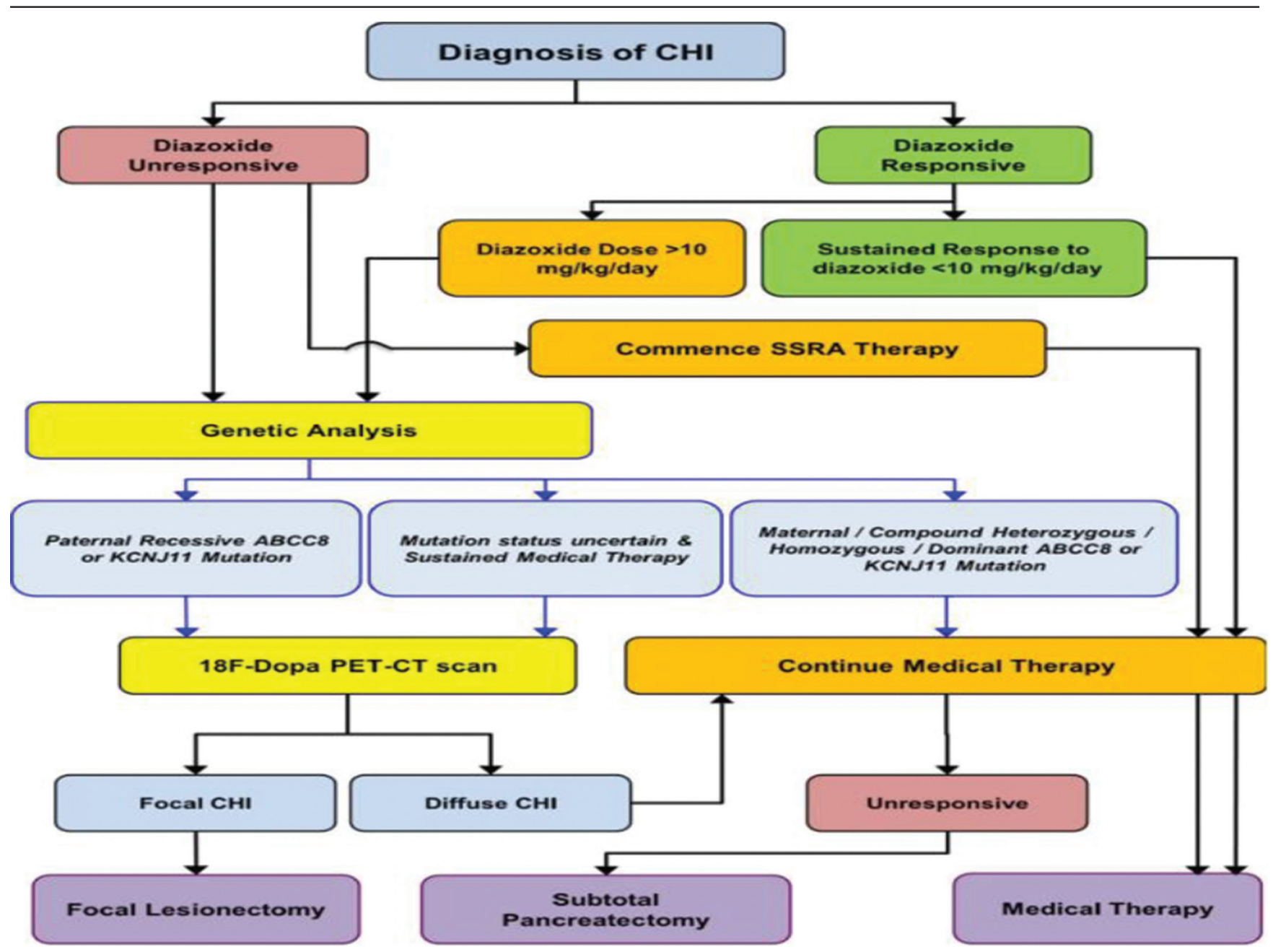

Figure 5: Diagnostic algorithm of insulinoma

$0.3 \mathrm{mg} / \mathrm{kg} / \mathrm{day}$, and octreotide $10 \mathrm{mcg} / \mathrm{kg} / \mathrm{day}$. The diazoxide could not be given due to the unavailability of the drug in Indonesia. The patient underwent laparotomy partial pancreatectomy.

The general outcome of insulinoma is unsatisfactory. Lee et al. [7] reported that the general outcome of congenital hyperinsulinism was poor with a high chance of having psychomotor or mental retardation (22\%) as well as seizure (33\%), and developed diabetes mellitus (38\%). The age at onset of hypoglycemia reflects the severity of $\mathrm{CHI}$. Welters et al. [8] reported that in surgically treated $\mathrm{CHI}$ patient's insulin treatment needs to be intensified to achieve good glycaemic control. Our data furthermore emphasize the need for improved medical treatment options for patients with diazoxide and/or octreotide unresponsive $\mathrm{CHI}$. The patient got seizure, which can increase the risk of having psychomotor or mental retardation as well as seizure. The patient also got hyperglycemia after the surgery. The heel-prick glucose level ranges between 223 and $307 \mathrm{mg} / \mathrm{dL}$. The patient was given insulin 1 unit every $6 \mathrm{~h}$ when glucose level $>200 \mathrm{mg} / \mathrm{dL}$. Patient fasting insulin level was $<2 \mu \mathrm{IU} / \mathrm{ml}$, (reference range 3.2-28.5 $\mu \mathrm{lU} / \mathrm{ml})$, low C-peptide level $(0.4 \mathrm{ng} / \mathrm{mL}$, reference range $0.9-7.1 \mathrm{ng} / \mathrm{mL})$. On the $4^{\text {th }}$ day after surgery, the patient blood glucose was normal. The patient is at risk of becoming diabetic. Blood glucose evaluation should be performed to monitor the risk of developed diabetes mellitus.

\section{Conclusion}

Insulinoma is a rare disease. The diagnosis was challenging. Early diagnosis and appropriate treatment are important. Medical therapy was initially chosen as the treatment, and surgery opted in an unresponsive $\mathrm{CHI}$ case. Comprehensive and multidisciplinary management is required for a better outcome. This case report presents the diagnostic work-up and management of a patient with a persistent hypoglycemia condition that was diagnosed as insulinoma.

\section{Patient Consent}


Consent to publish the case report was not obtained. This report does not contain any personal information that could lead to the identification of the patient.

\section{References}

1. Gomella TL, Cunningham MD, Eyal FG. Neonatology management, procedures, on-call problems, disease, and drugs. LANGE. 2013;25:427-36.

2. Lloyd RV, Osamura RY, Kloppel G, Rosai J. WHO classification of tumours of endocrine organs. World Health Organ. 2017;4:222-4.

3. Zhuo F, Anastasopoulou C. Insulinoma. Treasure Island, FL: StatPearls. 2019. p. 1-16.

4. Shin J, Gorden P, Libutti SK. Insulinoma: Pathophysiology, localization and management. Future Oncol. 2010;6(2):229-37. https://doi.org/10.2217/fon.09.165

PMid:20146582

5. Saneifard H, Tabari AK, Aghdam MK, Khorshidi MM, Sheikhy A. Sporadic insulinoma as a rare cause of recurrent hypoglycemia in children: A case report and literatur review. Hindawi. 2017;2017:4756793. https://doi. org/10.1155/2017/4756793

PMid:28512591

6. Mathur A, Gorden P, Libutti S. Insulinoma. Surg Clin North Am. 2009;89(5): 1-31. http://doi:10.1016/j.suc.2009.06.009

7. Lee CT, Liu S, Tung Y, Chiu P, Wu M, Tsai W. Clinical characteristics and long-term outcome of Taiwanese children with congenital hyperinsulinism. Diabetes J. 2015;35:1-5. http:// dx.doi.org/10.1016/j.jfma.2015.04.002

8. Welters A, Meissner T, Henn JG, Reiterer EF, Warncke K, Mohnike K, etal. Characterization of diabetes following pancreatic surgery in patients with congenital hyperinsulinism. J Rare Dis. 2018;13(1):230. http://doi.org/10.1186/s13023-018-0970-8

PMid:30577875 